\title{
ICT IN EDUCATION AS THE APPLIANCE OF THE DEVELOPMENT OF SPATIAL IMAGINATION OF LEARNERS
}

Viera TOMKOVA* Univerzita Konštantína Filozofa v Nitre

Přijato: 27. 10. 2015 / Akceptováno: 20. 11. 2015

Typ článku: Výskumný článok

DOI: $10.5507 /$ jtie.2015.016

Abstract: The report is addicted to the different means of learner's education with the support of IKT that develops their ability to read consciously, their spatial sensitivity, their ability of manipulation with objects in space and their ability to make their own graphical views of the sensed objects. The paper presents the research team results that have been achieved in the process of meeting goals of the KEGA project No. 035UKF-4/2012. The project concentrates on the development of the spatial imagination development of the lower secondary level learners. The main objective of the project was to design the methodology of technical education focused on the spacial imagination development and related graphic skills.

Key words: education, spatial imagination, educational ICT.

\section{IKT VO VZDELÁVANÍ AKO PROSTRIEDOK NA ROZVOJ PRIESTOROVEJ PREDSTAVIVOSTI ŽIAKOV}

Resumé: Príspevok je venovaný možnostiam vzdelávania žiakov s podporou IKT rozvijajúceho ich schopnost' čitat' text s porozumením, vnímat' priestor, manipulovat's objektami v priestore a vytvárat' vlastné grafické zobrazenia vnimaných objektov. Príspevok prezentuje výsledky riešitel'ského kolektivu, ktoré boli získané v rámci plnenia cielov projektu KEGA č. 035UKF-4/2012. Projekt bol zameraný na rozvoj priestorovej predstavivosti žiakov nižšieho sekundárneho vzdelávania. Hlavným cielom projektu bolo vypracovat' metodiku vzdelávania žiakov $v$ predmete technika zameranú na rozvoj priestorovej predstavivosti a s ňou súvisiacimi grafickými zručnost'ami.

Klíčová slova: vzdelávanie, priestorová predstavivost', vzdelácie IKT.

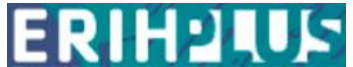

*Autor pro korespondenci: vtomkova@ukf.sk
This journal was approved on 2015-04-23 according to ERIH PLUS criteria for inclusion. 


\section{1 Úvod}

Informačné a komunikačné technológie (IKT) sú významnou hnacou silou ekonomického rozvoja a tiež sociálnych zmien $\mathrm{v}$ celosvetovom meradle. Ako uvádza Kozma (2005), v mnohých krajinách je potrebné investovat' do školskej reformy s ciel'om, zabezpečit jej hospodársky a sociálny rozvoj. Poukazuje na skutočnost', že toto je možné zabezpečit' len vtedy, ak sa spoločnost' zameria na rozvoj uvedených oblastí:

- ekonomickej,

- sociálnej,

- $\quad$ vzdelávania,

- vzdelávacích IKT.

$\mathrm{S}$ problematikou riešenou $\mathrm{v}$ príspevku priamo súvisia najmä posledné dve oblasti. Rozvoj v oblasti vzdelávania zahíňa vybudovanie a modernizovanie školských zariadení. Ďalej je potrebné sa zamerat' na inováciu osnov vzdelávania, na pedagogické kompetencie učitel'ov, ich tvorivost' a samozrejme na ich technologické zručnosti. Vývoj v oblasti vzdelávania nie je možný bez inovácie obsahu pedagogických a technologických vedomostí učitel’ov. Vývoj vo vzdelávaní podporujú vznikajúce organizačné siete učitel’ov a ich schopnost' zdiel'at' potrebné informácie. Posledným krokom v oblasti rozvoja vzdelávania je vypracovanie relevantných nástrojov na monitorovanie ukazovatelov úrovne učenia sa žiaka/študenta a zistené poznatky vediet' uplatnit' pri riešení odhalených problémov.

V oblasti rozvoja vzdelávacích IKT je potrebné investovat' do kvalitných informačných a komunikačných technológií a sietí, ktoré predstavujú základný predpoklad pre rozvoj zručností žiakov vo využívaní IKT pri riešení problémov reálneho sveta. Rozvoj zručností žiakov je možný len prípade, ak ich vyučujú učitelia schopní integrovat' IKT do vyučovacích osnov. Autori F. Potter a C. Darbyshire (2005) odporúčajú zamerat' sa pri ich zarad’ovaní do obsahu vzdelávania na štyri základné oblasti:

- vyhl'adávanie vecí,

- $\quad$ rozvíjanie nápadov a vytváranie lepších vecí,

- výmenu a zdiel'anie informácií,

- prieskumnú a tvorivú prácu ako prvok pre zlepšenie.

Učitel' vyučujúci s podporou vzdelávacích IKT si má vediet' vytvorit' databázu osvedčených postupov na aplikovanie IKT do vyučovania tak, aby prispeli k porozumeniu učiva, ku komplexnému riešeniu problémov a tiež ku kreativite žiakov (Y. K. Türel, T. E. Johnson, 2012).

Vzdelávacie IKT rozvíjajú aj komunikačné kompetencie žiakov, umožňujú im spolupracovat' online na úlohách, aj ked' nie sú prítomní v škole. Pozitívne hodnotíme aj skutočnost', že umožňujú zdiel'anie poznatkov a vedomostí medzi učitel'mi a žiakmi, a tiež sú nenahraditel’né pri overovaní účinnosti vzdelávania, hodnotení vplyvu IKT na učenie sa žiakov alebo študentov.

\section{2 Školská reforma v Slovenskej republike a jej vplyv na vzdelávanie žiakov}

Školská reforma sa začala v školskom roku 2008/2009 a predstavovala vel’a reformných zmien, ktoré mali za ciel' umožnit' učitel'om viac prispôsobit' vzdelávací proces potrebám a záujmom žiaka $\mathrm{s}$ ohl'adom na ich budúce uplatnenie sa na medzinárodnom trhu práce. Školská reforma slovenského školstva priniesla nie len zmeny 
v obsahu vzdelávania, ale aj v hodinovej dotácií na jednotlivé vyučovacie predmety. Do obsahu vzdelávania bola zaradená vzdelávacia oblast' Matematika a práca s informáciami, ktorá zahŕňa dva vyučovacie predmety: matematika a informatika. $\mathrm{V}$ predmete informatika sú žiaci vedení $\mathrm{k}$ pochopeniu základných pojmov, postupov a techník používaných pri práci $\mathrm{s}$ informáciami $\mathrm{v}$ počítačových systémoch. Vzdelávací obsah informatiky je rozdelený na pät tematických okruhov: Informácie okolo nás, Komunikácia prostredníctvom IKT, Postupy, riešenie problémov, algoritmické myslenie, Princípy fungovania a Informačná spoločnost'. Hodinová dotácia pre predmet informatika bola stanovená na 0,5 hodiny týždenne v ročníkoch 5 . až 9 . základnej školy v SR.

Nakol'ko svoj výskum zameriavame na možnosti zlepšenia čitatel'skej, matematickej a prírodovednej gramotnosti žiakov základnej školy implementáciou IKT do vzdelávania, pri analyzovaní účinnosti školskej reformy na úroveň vedomostí žiakov sa zameriavame na vzdelávaciu oblast' Človek a svet práce, do ktorej je zaradený vyučovací predmet technika. Pre technické vzdelávanie žiakov na základnej škole je charakteristické uplatňovanie nešpecifického transferu a divergentného myslenia. To znamená, že úroveň vedomostí žiakov v predmete technika je ovplyvňovaná dosiahnutou úrovňou ich vedomostí z matematiky, informatiky, fyziky, chémie, biológie, ale aj ich schopnostou čítat text $\mathrm{s}$ porozumením, vediet' ho analyzovat' a mat' osvojenú správnu odbornú terminológiu. $Z$ zvedeného je zrejmé, že dosiahnutá úroveň matematickej, čitatel'skej a prírodovednej gramotnosti žiakov priamoúmerne ovlyvňuje výsledky, ktoré dosahujú v testovaniach ich technických vedomostí a zručností.

Vplyvom reformy sa v Štátnom vzdelávacom programe znížila časová dotácia na vyučovací predmet technika, zabezpečujúci technické vzdelávanie na základnej škole, na 0,5 hodiny týždenne. Ďalšou zmenou bolo, že v 9. ročníku základnej školy sa predmet nevyučoval vôbec. To znamená, že žiaci 8. ročníka (vzdelávaní podl’a Štátneho vzdelávacieho programu ISCED 2 z roku 2008) by mali mat' osvojené rovnaké vedomosti z oblasti technického vzdelávania ako žiaci 9. ročníka spred reformy (vzdelávaní podla Učebných osnov z roku 1997). Pre úplnost' uvádzame, že pred reformou sa vyučovací predmet technika nazýval technická výchova a jeho hodinová dotácia bola 1 vyučovacia jednotka týždenne v ročníkoch 5. až 9. Testovaním žiakov v roku 2012 sme zistovali, či školská reforma prispela $\mathrm{k}$ zlepšeniu vedomostí a zručností žiakov v oblasti technického vzdelávania. Ak by sme zistili, že žiaci vzdelávaní po školskej reforme dosiahli v teste lepšie výsledky ako žiaci pred reformou, bolo by možné tvrdit', že školská reforma prispela k zlepšeniu čitatel'skej, matematickej a aj prírodovednej gramotnosti žiakov základnej školy.

\section{Metodika výskumu zameraného na úroveň vedomosti žiakov $v$ technickom vzdelávaní}

Didaktické testy na zistenie úrovne vedomostí a zručností v technickom vzdelávaní, realizované vo výskumných projektoch autorky (Tomková, 2013; Tomková a kol., 2014), obsahovali úlohy vyplývajúce zo vzdelávacieho obsahu predmetu technická výchova (technika). Predmetom výskumov boli vedomosti a zručnosti žiakov vo vyučovacích predmetoch technického charakteru s prihliadnutím na schopnost žiakov graficky komunikovat', ktoré sú uplatňované aj pri práci so vzdelávacími IKT. Pri riešení technických úloh mohli žiaci uplatnit' medzipredmetové vzt’ahy a vyššie myšlienkové operácie. 
Didaktické testy boli zostavené len z úloh predpísaných vzdelávacím štandardom $\mathrm{s}$ exemplifikačnými úlohami pre predmet technická výchova z roku 2002 a boli tvorené 18timi úlohami. Sedem úloh bolo $\mathrm{s}$ otvorenou odpoved'ou a jedenást' $\mathrm{s}$ zatvorenou odpoved’ou. Ked’že všetky úlohy $\mathrm{v}$ teste boli z predpísaného učiva platných učebných osnov pre 2. stupeň základnej školy v predmete technická výchova, očakávali sme $70 \%$ úspešnost' riešenia úloh žiakmi. Testovanie bolo realizované v rokoch 2005 a 2012.

Testovania sa zúčastnilo celkovo 296 respondentov. Výskumnú vzorku tvorilo v roku 2005 - 198 žiakov 9. ročníka a v roku 201298 žiakov 8. ročníka plneorganizovaných základných škôl v Slovenskej republike. Aby bolo možné štatisticky vyhodnotit' všetky sledované oblasti nášho záujmu, boli vytvorené subtesty overujúce jednotlivé oblasti:

1. schopnost' riešit' grafické úlohy,

2. schopnost' riešit' teoretické úlohy,

3. schopnost' riešit' úlohy vyžadujúce čítanie technickej dokumentácie,

4. schopnost' riešit' úlohy vyžadujúce zobrazenie riešenia vo forme statických obrazov,

5. schopnost' riešit' uzavreté úlohy,

6. schopnost' riešit' otvorené úlohy (Tomková, 2013).

Pracovnou hypotézou, na ktorú sme hl'adali odpoved' pomocou štatistických metód, bolo tvrdenie, že nebude zistený štatisticky významný rozdiel medzi výsledkami žiakov 9 . ročníka v roku 2005 a 8. ročníka 2012. Kým v roku 2005 boli žiaci vzdelávaní podla obsahu vzdelávania predpísaného Učebnými osnovami pre predmet technická výchova na 2. stupni základnej školy z roku 1997 (Krušpán, 1997), žiaci 8. ročníka boli vzdelávaní podla Štátneho vzdelávanieho programu z roku 2008 ICSED 2 (www.statpedu.sk).

\section{Výsledky výskumu}

Celkovú úspešnost' respondentov v riešení jednotlivých úloh uvádzame v tabul'ke č. 1 . Na základe porovnania stredných hodnôt (aritmetický priemer) môžeme konštatovat', že medzi výsledkami žiakov 9. ročníka z roku $2005(50,3 \%)$ a 8. ročníka $2012(26,7 \%)$ bol zistený významný rozdiel $(23,6 \%)$ v prospech 9 . ročníka 2005 a to znamená, že školská reforma nepriniesla požadované zlepšenie vedomostí a zručností žiakov základnej školy v oblasti technického vzdelávania.

Tabul'ka 1: Celková úspešnost' riešenia úloh žiakmi v teste v rokoch 2005 a 2012.

\begin{tabular}{|c|c|c|c|c|c|c|c|c|c|}
\hline \multirow{2}{*}{ ročník } & \multicolumn{8}{|c|}{ č́slo úlohy (vyhodnotenie $\%$ ) } \\
\cline { 2 - 10 } & 1 & 2 & 3 & 4 & 5 & 6 & 7 & 8 & 9 \\
\hline 9. roč. (2005) & 86,4 & 83,3 & 80,3 & 52,0 & 45,2 & 48,5 & 63,1 & 51,5 & 58,1 \\
\hline 8. roč. (2012) & 76,5 & 48,0 & 60,2 & 13,8 & 28,6 & 35,7 & 30,6 & 26,5 & 27,6 \\
\hline
\end{tabular}

\begin{tabular}{|c|c|c|c|c|c|c|c|c|c|c|}
\hline \multirow{2}{*}{ ročník } & \multicolumn{7}{|c|}{ číslo úlohy (vyhodnotenie $\%$ ) } & \multirow{2}{*}{ Spolu } \\
\cline { 2 - 12 } & 10 & 11 & 12 & 13 & 14 & 15 & 16 & 17 & 18 & \\
\hline 9. roč. (2005) & 79,3 & 49,0 & 32,8 & 41,7 & 60,6 & 19,7 & 22,7 & 47,5 & 71,7 & $\mathbf{5 0 , 3}$ \\
\hline 8. roč. (2012) & 44,9 & 22,4 & 5,6 & 19,9 & 41,8 & 14,3 & 6,1 & 19,4 & 51,0 & $\mathbf{2 6 , 7}$ \\
\hline
\end{tabular}

Zaujímalo nás, či zistený rozdiel medzi získanými výsledkami v testoch a subtestoch, ktoré dosiahli žiaci 9. ročníka v roku 2005 a žiaci 8. ročníka 2012 je štatisticky významný rozdiel. Použili sme Wilcoxonov dvojvýberový test na zistenie, či zistené rozdiely medzi 
žiakmi 8. ročníka (2012) a 9. ročníka (2005) v teste (a aj jednotlivých subtestoch) sú aj štatisticky významné. Testovaná bola nulová hypotéza:

$\mathrm{H}_{0}$ : V pozorovanom znaku - výsledkoch testu (subtestu) nie je štatisticky významný rozdiel medzi pozorovanými skupinami vo výsledkoch, ktoré žiaci dosiahli $\mathrm{v}$ teste (subteste); oproti alternatívnej hypotéze:

$\mathrm{H}_{1}$ : V pozorovanom znaku - výsledkoch testu (subtestu) je štatisticky významný rozdiel medzi pozorovanými skupinami vo výsledkoch, ktoré žiaci dosiahli v teste (subteste).

$\mathrm{Na}$ štatistické testovanie sme použili program Statistica a na overenie nulovej a alternatívnej hypotézy Shapirov - Wilkov neparametrický test. Výsledky neparametrického testu sú uvedené v tabul'ke č. 2. Nulovú hypotézu $\mathrm{H}_{0}$ zamietame vtedy, ak hodnota pravdepodobnosti $\mathrm{p}<0,05$ na zvolenej hladine významnosti $\alpha=0,05$. Táto podmienka bola splnená v teste a všetkých subtestoch (tabul'ka č. 2).

Tabul'ka 2: Výsledky Wilcoxonovho dvojvýberového testu pre 9. ročník v roku 2005 a 8 . ročník 2012.

\begin{tabular}{|l|r|r|r|}
\hline & \multicolumn{1}{|c|}{ Rank Sum } & \multicolumn{1}{c|}{ Rank Sum } & \multicolumn{1}{c|}{ p-level } \\
\cline { 2 - 4 } & 9. roč. (2005) & 8. roč. (2012) & \\
\hline test & 36644,50 & 7311,50 & 0,00 \\
\hline grafické úlohy & 34270,00 & 9686,00 & 0,00 \\
\hline teoretické úlohy & 35741,50 & 8214,50 & 0,00 \\
\hline čítanie technickej dokumentácie & 34708,50 & 9247,50 & 0,00 \\
\hline statické obrazy & 34569,50 & 9386,50 & 0,00 \\
\hline zatvorené úlohy & 34365,00 & 9591,00 & 0,00 \\
\hline otvorené úlohy & 35420,50 & 8535,50 & 0,00 \\
\hline
\end{tabular}

Z tabul'ky č. 2 je zrejmé, že vo všetkých subtestoch (na základe vypočítanej hodnoty testovacej štatistiky $Z$ a hodnoty pravdepodobnosti $p=0,00$, na hladine významnosti $\alpha$ $=0,05)$, bol zistený štatisticky významný rozdiel medzi výsledkami žiakov 8 . ročníka (2012) a 9. ročníka (2005), v prospech žiakov 9. ročníka základnej školy.

Ako vidiet’ z grafu č. 1, žiaci vzdelávaní po reforme školstva (8. ročník 2012) nedosiahli ani v jednej úlohe úspešnost’ predrefomných žiakov 9. ročníka základnej školy $\mathrm{z}$ roku 2005. 


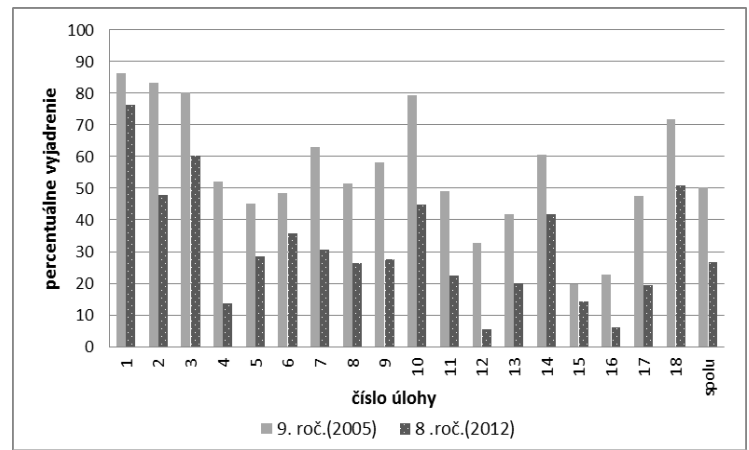

Graf 1: Celková úspešnost' riešenia jednotlivých úloh v didaktických testoch.

Všetky hodnotené oblasti priamo súvisia s efektivitou vzdelávania pomocou IKT, ktoré poskytujú žiakom virtuálny a často skreslený obraz skutočnosti. Zobrazenia skutočných objektov sú znázornené $\mathrm{v} 2 \mathrm{D}$ a pre žiaka môže byt' náročné zorientovat' sa $\mathrm{v}$ danom zobrazení a vediet' si sledované objekty predstavit' aj v reálnom svete.

\section{Diskusia a závery vyplývajúce $\mathrm{z}$ výsledkov výskumu}

Podrobnou analýzou výsledkov nami realizovaného výskumu na vzorke žiakov 8 . ročníka základnej školy v roku 2012 sme odhalili, v ktorých sledovaných oblastiach dosahujú žiaci najnižšie skóre:

- testovanie priestorovej predstavivosti $-15,4 \%$,

- $\quad$ schopnost' zakreslit' riešenie - 19,9\%,

- $\quad$ schopnost' čítat dokumentáciu a statické obrazy $-22,2 \%$,

- teoretické vedomosti - $42,1 \%$,

- riešenie otvorených úloh (podnetové úlohy) $-15,3 \%$.

Celkový výsledok 26,7 \% v testovaní žiakov 8. ročníka v roku 2012 naznačuje, že úroveň vedomostí žiakov v technickom vzdelávaní je na nízkej úrovni, čo zodpovedá aj hodnoteniam OECD PISA 2012 pre oblast' čitatel'skej, matematickej a aj prírodovednej gramotnosti (www.nucem.sk).

Z uvedených výsledkov výskumu vyplýva, že školská reforma nepriniesla pozitívne zmeny na úroveň technického vzdelávania žiakov na základnej škole v Slovenskej republike. Výskum poukázal na skutočnost', že slovenskí žiaci nevedia riešit úlohy, $\quad \mathrm{v}$ ktorých je potrebné uplatnit' priestorovú predstavivost', nevedia čítat' text s porozumením, nevedia vyhl'adat' potrebné informácie v dokumente vo forme statických obrazov (podnetové úlohy). Ako sme už uviedli, všetky sledované oblasti ovplyvňujú účinnost' IKT vo vzdelávaní žiakov.

Nakol'ko školská reforma z roku 2008 v SR nepriniesla očakávané zlepšenie vedomostí a zručností žiakov základnej školy, je potrebné hladat' možnosti, ktoré by daný stav zmenili. Autorka príspevku, spolu so svojím riešitel'ským kolektívom, navrhla v roku 2014 model vzdelávania žiakov 5. až 9. ročníka s využitím IKT. 
Viacerí odborníci zaoberajúci sa využívaním IKT vo vzdelávaní uvádzajú, že prostriedok, ktorý vo vyučovaní prispieva $\mathrm{k}$ názornosti a tiež $\mathrm{k}$ efektivizácii vzdelávania žiakov a študentov, je interaktívna tabul'a (IT) (F. Potter, C. Darbyshire, R. B. Kozma, R. J. Marzano). Rovnaký trend je aj vo vzdelávaní žiakov na základnej škole v Slovenskej republike, kde sa stále viac využívajú informačno-komunikačné technológie na sprostredkovanie učiva žiakom. Na prvom stupni základnej školy (ročníky 1. až 4) žiaci pracujú s interaktívnymi tabul'ami a formou hry alebo logických úloh sa oboznamujú s novým učivom. Na druhom stupni základnej školy (ročníky 5. až 9.) žiaci pracujú nie len $\mathrm{s}$ interaktívnou tabul'ou, ale aktívne pracujú aj $\mathrm{s}$ informačno-komunikačnými technológiami vo vyučovaní humanitných a aj prírodovedných predmetov, ako sú matematika, fyzika, informatika, chémia a technika. IKT sú hodnotené učitel'mi ako motivačné prostriedky vo vzdelávaní žiakov.

Problematikou efektivity vzdelávania žiakov s podporou IT sa vo svojom výskume zaoberajú aj Türel a Johnsom (2012), ktorí realizovali výskum na vzorke 174 učitel’ov učiacich žiakov vo veku od 6 do 12. Ako uvádzajú, až 91,4 \% respondentov súhlasí, že IT poskytuje prostriedky na lepšiu názornost' a predstavivost'. Rovnako konštatujú, že IT prispieva $\mathrm{k}$ l'ahšiemu $(64,0 \%)$ a rýchlejšiemu zapamätaniu si učiva $(65,4 \%)$. Ako uvádza R. J. Marzano (2009), používaním grafických a iných vizuálne prezentovaných informácií pomocou IT, došlo u testovaných študentov k zlepšeniu ich výkonu o 26 percentilov. Z vyššie uvedeného môžme predpokladat', že IT pozitívne ovplyvňuje schopnost' žiakov porozumiet' textu.

Ciel’om nami navrhnutého modelu vzdelávania je prispiet' $\mathrm{k}$ rozvoju najmä nasledovných oblastí rozvoja osobnosti žiakov:

- $\quad$ osvojenie si pojmov,

- vnímanie priestoru,

- schopnost' manimulovat's objektmi v predstavách, bez prítomnosti reálneho objektu,

- schopnost' uplatnit' teoretické vedomosti pri zakresl’ovaní riešenia úloh.

Rozvojom uvedených oblastí osobnosti žiaka sa prispieva aj $\mathrm{k}$ efektívnejšiemu získavaniu a osvojovaniu informácií vo vyučovaní, poskytovaných pomocou IKT. Základným ciel’om nami realizovaného výskumu je zistit', či na rozvoj sledovaných oblastí má výraznejší vplyv manipulácia s reálnými telesami alebo práca $\mathrm{s}$ ich virtuálnymi zobrazeniami pomocou IKT. Bola stanovená hypotéza $\mathrm{H}_{0}$ : Medzi kontrolnou a experimentálnou skupinou nebude zistený štatisticky významný rozdiel v schopnosti žiakov zobrazit' vnímané teleso podl'a pravidiel pravouhlého premietania.

Výskumná vzorka je tvorená žiakmi 6. a 7. ročníka ZŠ. Kontrolná skupina je vzdelávaná pomocou dvadsiatich reálnych modelov vybraných telies. Experimentálna skupina je vyučovaná pomocou IKT, t.j. pravidlá pravouhlého premietania si žiaci osvojujú pomocou manipulácie s virtuálnymi 3D modelmi vytvorenými v programe Alibre Design. Všetky virtuálne telesá $\mathrm{v}$ počte 20 kusov boli exportované do formátu pdf.

Pre každé teleso v 3D zobrazení je vytvorený vlastným súbor. Pdf formát umožňuje žiakovi prezerat' si dané teleso, pričom je možné menit' samotné zobrazenie vo viacerých modifikáciách. Základná manipulácia s obrazom je vel'mi jednoduchá a dá sa realizovat' 
pomocou uchopenia myšou. Pre lepšiu orientáciu pri otáčaní virtuálního telesa je na obraze znázornený aj súradnicový systém osí x, y, z. Ukážka vzhl’adu zobrazenia telesa je na obrázku 1. S telesom je možné rotovat' v l'ubovol'nom smere, čo umožňuje zvolit' si rôzne pohl'ady na teleso (nárys, pôdorys, bokorys a pod.). Práca vo virtuálnom zobrazení telies je vel'mi názorná pri vysvetl’ovaní rozdielu medzi rezom a prierezom. Táto téma je pre žiakov vel'mi náročná nie len v technike, ale najmä v geometrii.

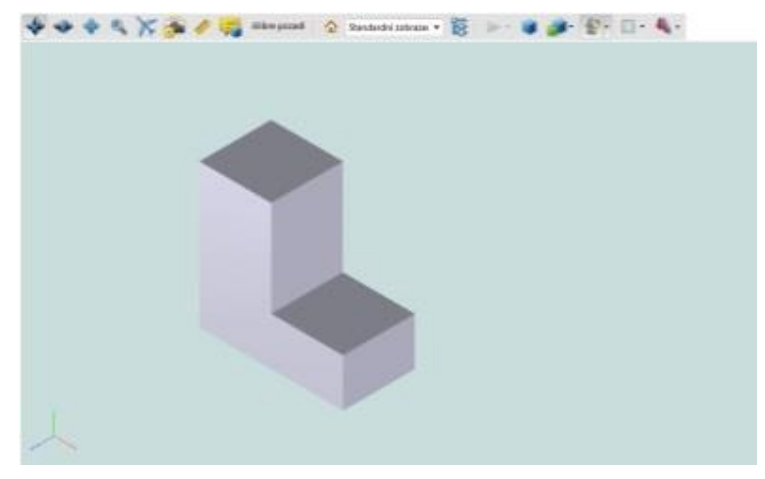

Obrázok 1: Ukážka virtuálneho 3D modelu zloženého telesa.

Navrhnutý súbor interaktívnych učebných pomôcok pre technické vzdelávanie je zameraný na rozvoj priestorovej predstavivosti žiakov tak, aby dokázal: vnímat' modely základných a zložených geometrických telies v skutočnosti a vo virtuálnom 3D zobrazení, vedel manipulovat' a orientovat' sa vo virtuálnom zobrazení daných telies a následne zhotovovat' základné zobrazenia $\mathrm{v} 2 \mathrm{D}$ zobrazení na papieri. Reálne a aj virtuálne modely môžeme rozdelit' do troch základných skupín: hranaté, valcové a kužel'ové. $Z$ hl'adiska názornosti vo vyučovaní je virtuálne zobrazenie telies prínosom v tom, že umožňuje teleso zobrazit' vo forme priehl'adného zobrazenia, čo umožňuje žiakom vidiet' aj skryté (neviditel'né) hrany. Ukončenie výskumu je naplánované na máj 2016 a zverejnenie získaných výsledkov z výskumu v novembri 2016.

\section{Záver}

Vzdelávanie v SR bude opät' inovované od septembra 2015. Ciel’om inovácie je zlepšenie úrovne vzdelávania žiakov na základnej škole, nakol'ko slovenkí žiaci dosahujú signifikantne nízke výsledky vo všetkých sledovaných oblastiach medzinárodného certifikovaného merania OECD PISA. Z výskumov vyplýva, že jednou z možností zefektívnenia vzdelávacieho procesu je implementácia vzdelávacích IKT do vyučovania, s čím súvisí tvorba multimediálnych pomôcok vhodných pre IT (Kozma, 2005, Bánesz Hašková, 2014, Potter - Darbyshire, 2005). Výskumom sme poukázali, na ktoré oblasti rozvoja osobnosti žiaka je potrebné sa zamerat', ak chceme zlepšit' jeho úspešnost' v riešení testových úloh: porozumenie textu, orientácia v prietore, aplikácia vedomostí v iných súvislostiach a vyhl'adávanie potrebných informácií zo statických obrazov (graf, schéma, tabul'ka, obrázok a pod.). Očakávame, že vyhodnotením výsledkov výskumu, ktorý v súčasnom období realizuje, sa potvrdí pozitívny vplyv IKT na schopnosti žiakov zobrazovat' vnímané telesá pomocou pravidiel názorného premietania. 


\section{Literatúra}

Bánesz, G. - Hašková, A. (2014) E-learning assisted teaching of technical subjects In: Aplication of information and Communication Technologies - AICT 2014. Astana: IEEE, 2014 s. 427-431. ISBN 978-1-4799-4120-9 2

Kozma, R. B. (2005) National policies than connect ICT-based education reform to economic and social development. In: Human Technology: An Interdisciplinary Journal on Humans in ICT Environments, vol. 1 (2), pp. 117-156, October 2005. ISSN 1795-6889. Krušpán, I. (1997) Učebné osnovy technickej výchovy pre 5 až 9.ročník základnej školy, 1997. Dostupné na www:

http://www2.statpedu.sk/buxus/generate_page.php_page_id=385.html

Marzano, R. J. (2009) The Art and Science of Teaching/Teaching with Interactive Whiteboards. In: ASCD Educational Leadership: Multiple Measures, vol. 67, Nr. 3, s. 8082, November 2009. Dostupné na www:

http://www.ascd.org/publications/educational-leadership/nov09/vol67/num03/Teachingwith-Interactive-Whiteboards.aspx

Potter, F. - Darbyshire, C. (2005)Understanding and Teaching the ICT National Curriculum. London: David Fulton Publishers, 2005, 207 s. ISBN 1843211336. Retrieved July 6, 2015. Dostupné na www:

https://www.waterstones.com/book/understanding-and-teaching-the-ict-nationalcurriculum/franc-potter/carol-darbyshire/9781843121336

Štátny vzdelávací program pre 2. stupeñ základnej školy v Slovenskej republike ISCED 2 - nižšie sekundárne vzdelávanie. Dostupné na www:

http://www.statpedu.sk/files/documents/svp/2stzs/isced2/isced2_spu_uprava.pdf

Tomková, V. a kol. (2014) Priestorová predstavivost' v školskej praxi. Nitra: UKF v Nitre, 2014. 158 s., ISBN 978-80-558-0711-9.

Tomková, V. (2013) Technická neverbálna komunikácia. Nitra: UKF v Nitre, 2014, 204 s. ISBN 978-80-558-0367-8.

Türel, Y. K. - Johnson, T. E. (2012) Teachers' Belief and Use of Interactive Whitebroards for Teaching and Learning. In: Educational Technology \& Society, vol. 15 (1), s. 381-394, 2012. Dostupné na www:http://www.ifets.info/journals/15 1/32.pdf

Ukážky uvolnených úloh z matematickej gramotnosti PISA 2012. Dostupné na www: http://www.nucem.sk/documents//27/medzinarodne_merania/pisa/publikacie_a_disemina cia/4 ine/ukazky uloh z matematickej gramotnosti.pdf 